\title{
References
}

Coe, K. \& Cheeney, R. F. 1972: Preliminary results of mapping in Liverpool Land, East Greenland. Rapp. Grønlands geol. Unders. 48, 7-20.

Hansen, B. T., Steiger, R. H. \& Henriksen, N. 1972: The geochronology of the Scoresby Sund area. Rapp. Grønlands geol. Unders. 48, 105-107.

Henriksen, N. \& Higgins, A. K. 1969: Preliminary results of mapping in the crystalline complex around Nordvestfjord, Scoresby Sund, East Greenland. Rapp. Grønlands geol. Unders. 21, 5-20.

Henriksen, N. \& Higgins, A. K. 1970: Preliminary results of mapping in the crystalline complex of Renland, the southern Stauning Alper and south-west Liverpool Land, Scoresby Sund, East Greenland. Rapp. Grønlands geol. Unders. 30, 5-17.

Henriksen, N. \& Higgins, A. K. 1971: Preliminary results of mapping in the crystalline complex around Rypefjord and Rødefjord, and on northern Milne Land, Scoresby Sund, East Greenland. Rapp. Grønlands geol. Unders. 37, 5-18.

Olesen, O. B. \& Reeh, N. 1969: Preliminary report on glacier observations in Nordvestfjord, East Greenland. Rapp. Grønlands geol. Unders. 21, 41-53.

Watt, W. S. \& Watt, M. 1971: Preliminary report of the mapping of the basalts of parts of Milne Land and Gåseland. Rapp. Grønlands geol. Unders. 37, 42-50.

Wenk, E. 1961: On the crystalline basement and the basal part of the pre-Cambrian Eleonore Bay Group in the southwestern part of Scoresby Sund. Meddr Grønland 168, 1, 54 pp.

\section{SAMPLING FOR OIL SOURCE ROCK ANALYSIS, SCORESBY SUND REGION, CENTRAL EAST GREENLAND}

\section{N. B. H. Stevens and Katharina Perch-Nielsen}

From the 12th to 25 th of July outcrops of bituminous shales and limestones at four localities were visited by the authors. Three of the outcrops, at Fleming Fjord opposite Wegener Halv $\varnothing$, at Nathorst Fjord and at Edderfugledal were of Myalina Limestone of the Triassic Solfaldsdal Member. The fourth locality in the Schuchert Flod area near the western edge of the sedimentary basin involved the Upper Permian Posidonia Shale Member.

The main purpose of the field work was for Stevens, as the Survey's consultant, to get acquainted with the geology of the main rock types in the field, mainly with respect to environments of deposition and also to discover indications or proofs of the migration of hydrocarbons. Perch-Nielsen being conversant with the geology from previous seasons mapping acted as field guide. Samples were coilected for analysis to increase the information already obtained from samples collected by the Survey during previous mapping.

In a fault zone near the outcropping Posidonia Shale, the presence of $\mathrm{H}_{2} \mathrm{~S}$ was noted which is most probably related to the bituminous intercalations found within that member. One of the collected samples may contain traces of migrated 
hydrocarbons. Clear indications of migration of larger extent were not observed neither in or near the Myalina Limestone outcrops.

The locality at Nathorst Fjord was partly covered by snow which prevented the detailed investigation regarding possible migration phenomena. It was observed however that cyclic sedimentation appears to have been important during the deposition of the Myalina Limestone. Variations in composition and thickness of the Myalina Limestone and its bituminous intercalations were noted. A sample collected previously from this locality has been determined to be a good source rock, whereas samples from other localities produced negative results by earlier analysis.

N. B. H.S., Olexcon International $N . V$., The Hague, Netherlands.

K.P-N., Institut for historisk Geologi og Palceontologi, University of Copenhagen, $\emptyset$ stervoldgade 10 , 1350 Copenhagen $K$.

\section{PROCESSING AND INTERPRETATION OF RADIOMETRIC FLIGHT DATA FROM CENTRAL EAST GREENLAND}

\section{Leif Løvborg and Bjarne Leth Nielsen}

The data obtained from the aeroradiometric survey carried out by GGU in 1971 in the Scoresby Sund region (Nielsen, 1972), have been digitised and stored on magnetic tape in order to permit a processing on the Burroughs B-6700 computer housed at the Danish Atomic Energy Commission's Research Establishment at Ris $\varnothing$. This note describes the method of processing these data, leading to an interpretation and correlation with the bedrock geology of a selected area.

\section{Processing of data}

The strip-chart records produced by the four-channel airborne gamma spectrometer and the radar altimeter were traced with India ink on $36 \mathrm{~cm}$ wide sheets of transparent paper. Next, the five curves on each sheet were successively digitised in the form of punched paper tape using an optical curve follower controlled by the Ris $\varnothing$ EAI-680/PDP-8 hybrid computer. Finally, all punched-tape information was directly transferred to magnetic tape on the B-6700 computer.

The data processing began with a recovery of gamma spectrometer count-rates and flying altitudes, expressed in units of counts per second and feet respectively. Cards were punched describing the various positions of the ratemeter range selectors in the course of the survey, and these cards served as input to a special computer programme which converted the data on the magnetic tape into true 